\title{
SEASONAL ABUNDANCE AND MORTALITY OF Oebalus poecilus (DALLAS) (HEMIPTERA: PENTATOMIDAE) IN A HIBERNATION REFUGE
}

\author{
SANTOS, R. S. S. ${ }^{1}$, REDAELLI, L. R. ${ }^{2}$, DIEFENBACH, L. M. G. ${ }^{3}$, ROMANOWSKI, H. P. \\ PRANDO, H. F. ${ }^{5}$ and ANTOCHEVIS, R. C. ${ }^{2}$ \\ ${ }^{1}$ Depto. Estudos Agrários, UNIJUI, Rua do Comércio, 3000, CEP 98700-000, Ijuí, RS, Brazil \\ ${ }^{2}$ Depto. Fitossanidade, UFRGS, Av. Bento Gonçalves, 7712, CEP 91540-000, Porto Alegre, RS, Brazil \\ ${ }^{3}$ IPB-LACEN-RS, Fundação Estadual de Produção e Pesquisa em Saúde, \\ Av. Ipiranga, 5400, CEP 90610-000, Porto Alegre, RS, Brazil \\ ${ }^{4}$ Depto. Zoologia, UFRGS, Av. Bento Gonçalves, 9500, Bloco IV, Prédio 43435, CEP 91501-970, Porto Alegre, RS, Brazil \\ ${ }^{5}$ Epagri/Estação Experimental de Itajaí, C. P. 277, CEP 88301-970, Itajaí, SC, Brazil \\ Correspondence to: Luiza Rodrigues Redaelli, Depto. Fitossanidade, UFRGS, Av. Bento Gonçalves, 7712, CEP 91540-000, \\ Porto Alegre, RS, Brazil, e-mail: luredael@ufrgs.br \\ Received February 10, 2004 - Accepted September 27, 2004 - Distributed May 31, 2006
}

(With 2 figures)

\begin{abstract}
Oebalus poecilus (Dallas) is an important pest affecting irrigated rice in Rio Grande do Sul, Brazil. It hibernates during the coldest months of the year in refuges such as bamboo litter. This study examined $O$. poecilus hibernation to determine the causes of mortality during this period. The study was conducted in a $140 \mathrm{~m}^{2}$ bamboo plantation located in a rice-growing area in Eldorado do Sul County $\left(30^{\circ} 02^{\prime} \mathrm{S}\right.$ and $51^{\circ} 23^{\prime}$ W), RS. During June 2000 to April 2002, 63 samples of litter were taken in weekly or fortnightly intervals, and the number of bugs recorded in the laboratory. The arrival at the hibernation site (bamboo litter) began in the first fortnight of March, and was completed in the beginning of May. O. poecilus left this refuge from middle October to the end of December. Parasitism by tachinid flies and Beauveria bassiana (Bals.) Vuill. fungus were the most important mortality factors.
\end{abstract}

Keywords: overwintering, small rice stink bug, parasitism, Beauveria bassiana.

\section{RESUMO}

\section{Abundância sazonal e mortalidade de Oebalus poecilus (Dallas) (Hemiptera: Pentatomidae) no refúgio de hibernação}

Oebalus poecilus (Dallas) é praga importante do arroz irrigado no Rio Grande do Sul, Brasil. Este inseto hiberna durante os meses mais frios em refúgios como o folhedo de bambu. Este estudo objetivou elucidar a hibernação de $O$. poecilus e determinar as causas de mortalidade durante este período. O estudo foi realizado em um bambuzal com cerca de $140 \mathrm{~m}^{2}$, situado em área orizícola, em Eldorado do Sul (3002' S e $51^{\circ} 23^{\prime}$ W), RS. De junho/2000 à abril/2002, foram realizadas 63 amostragens de folhedo, em intervalos semanais ou quinzenais e o número de percevejos registrado em laboratório. A entrada no refúgio de hibernação (folhedo de bambu) iniciou na primeira semana de março, completando-se no início de maio. $O$. poecilus abandonou o refúgio da metade de outubro até o final de dezembro. O parasitismo por mosca (taquinídeos) e o fungo Beauveria bassiana (Bals.) Vuill. foram os principais fatores de mortalidade.

Palavras-chave: hibernacão, percevejo-do-arroz, parasitismo, Beauveria bassiana . 


\section{INTRODUCTION}

The small rice stink bug, Oebalus poecilus (Dallas), occurs in almost all South American countries (Becker \& Grazia-Vieira, 1971; GraziaVieira \& Casini, 1973). It feeds on developing grains of various plant species, both wild and cultivated (Albuquerque, 1991), and is a major pest in irrigated rice (Gallo et al., 2002).

Most studies on $O$. poecilus have concentrated on the active phase of its life cycle, the damages it inflicts, and the testing of its control by insecticides (Sutherland et al., 2002). Few data are found on survival strategy of this bug when rice is not available, and when inactive during winter. Diapause strategy presented by a heteropterous species (Pentatomidae) has been investigated for many other species worldwide. In Japan, Kiritani et al. (1962) and Kiritani (1963) reported that adults of the third generation of Nezara viridula (L.) spend the winter in tussocks, resuming their feeding and reproduction activities in the spring, with hibernating females presenting atrophied ovaries and a great amount of body fat. In Canada, Oebalus pugnax (F.) hibernates in grass tussocks from October to April, showing great body fat amounts in the abdominal cavity and immature reproductive organs (Nilakhe, 1976). Aner (1991) in Eldorado do Sul, RS, reported grass tussocks as the hibernation site of adult Tibraca limbativentris Stäl. In northern Paraná State, Panizzi \& Niva (1994) observed, from June to October, under foliage litter high densities of Euschistus heros (F.) (more than 50 individuals $/ \mathrm{m}^{2}$ ) with altered color. Panizzi \& Vivan (1997), besides characterizing the dormancy of E. heros as an oligopause, verified that the population of this insect increases under pigeon pea, Cajanus cajan (L.), foliage litter from April to August, gradually decreasing from September to November, with no individuals found in the site during DecemberMarch. Mourão \& Panizzi (2000) verified that during the fall/winter, E. heros presents immature reproductive organs and little-developed humeral spines that indicate diapausing individuals.

Information on $O$. poecilus dormancy is essential to explain its population dynamics, and to design integrated management programs. Therefore, a study was conducted on this insect's hibernation and to determine mortality causes during this period.

\section{MATERIAL AND METHODS}

The study was conducted from June 2000 to April 2002 in a bamboo tussock, $260 \mathrm{~m}$ long, $2 \mathrm{~m}$ wide and east-west orientation, formed by Bambusa tuldoides (Munro) (Gramineae), in Eldorado do Sul County, RS ( $30^{\circ} 02^{\prime} \mathrm{S}$ and $\left.51^{\circ} 23^{\prime} \mathrm{W}\right)$. The litter layer averaged $6.7 \mathrm{~cm}$ along the entire bamboo growth used as a hibernation site by $O$. poecilus (Santos et al., 2003).

The study area consisted of $70 \mathrm{~m}$ of bamboo growth in which seven areas, $10 \mathrm{~m}$ long on each side (north and south) were demarcated, totaling 14 areas, each one of which was subdivided into ten $1 \mathrm{~m} \times 1 \mathrm{~m}$ areas. Each sub-area was subdivided into $20 \mathrm{~cm}$ portions, perpendicularly to the bamboo growth length, totaling five $0.2 \mathrm{~m}^{2}$ sections $/ \mathrm{m}$.

A random sampling stratified system was used, with four $300 \mathrm{~cm}^{3}$ units of foliage litter taken from each of the 14 areas, from the subareas, and from portions previously turned over at weekly or fortnightly intervals, totaling 56 sampling units on each sampling occasion. In the laboratory, the bugs (live and dead) were extracted from the samples, sexed, and counted. The live individuals were dissected to confirm the diapause state.

$O$. poecilus hibernation periods were identified and subdivided by using $G$ statistics to examine frequency distribution homogeneity of the number of individuals/sample unit. The observed proportions of dead individuals along hibernation and the sexual ratio at each sampling were compared by chi-square statistics $(\mathrm{P} \leq 0.05)$. The trend test was used to determine variation of the dead insect proportion along the study. Microsoft Excel and Bioestat 2.0 software were used for calculations.

\section{RESULTS AND DISCUSSION}

\section{Adult capture and sex ratio}

During the study period, 63 samplings were taken and 4,162 O. poecilus adults were collected from the bamboo litter. The high number of bugs captured in a diapause state indicates that the bamboo litter is a favorable place for its hibernation. Mielitz et al. (1996) registered the rice water weevil, Oryzophagus oryzae Costa Lima (Coleoptera: Curculionidae), hibernating in similar conditions in a location from which they infested rice plantations. 
The sex ratio of bugs collected (live or dead) did not differ statistically from the expected 1 female: 1 male $(\mathrm{P}>0.05)$ in over $90 \%$ of the sampling occasions. The sex ratio during hibernation represents an important component of population dynamics. Kiritani et al. (1962) verified that in different hibernation sites the survival of $N$. viridula females was $11 \%$ higher than that of males. The difference in the mortality rate in relation to sex changed the sex ratio from $48.3 \%$ to $54.4 \%$, before and after dormancy, respectively. Negron \& Riley (1991) registered a sex ratio of 1:1 during hibernation of Blissus leucopterus leucopterus (Say) (Hemiptera: Lygaeidae) in Louisiana, USA. Results obtained for the small stink bug indicate that both females and males hibernate in the same place and are equally vulnerable to mortality factors during this period.

\section{Seasonal abundance of adults}

Temporal variation in the number of O. poecilus/sampling of litter (Fig. 1) allowed distinguishing three periods during the hibernation phase: active occupation (arrival); relative populational stability in the refuge (intermediate); and departure from the refuge (departure). From January to February (summer), no live individuals were found in the refuge, similar to what was recorded for $E$. heros in a hibernation site during the summer months (Panizzi \& Vivan, 1997).

In 2001, the number of $O$. poecilus adults in the bamboo litter tended to rise from the second fortnight of March (beginning of fall) until the first fortnight of May (end of fall), which is the arrival period in the refuge (ca. 60 days) (Fig. 1). From the end of the first fortnight of May until the second fortnight of October (spring), the relative populational stability period in the site (ca. 180 days) was observed. Departure from the refuge occurred from the second fortnight of October until the second fortnight of December (end of spring), when bugs started feeding and reproduction.

In 2002, the arrival period of adults at the hibernation site began in the second fortnight of April. This delay in relation to the preceding year was due to a late rice seeding period. Movement into

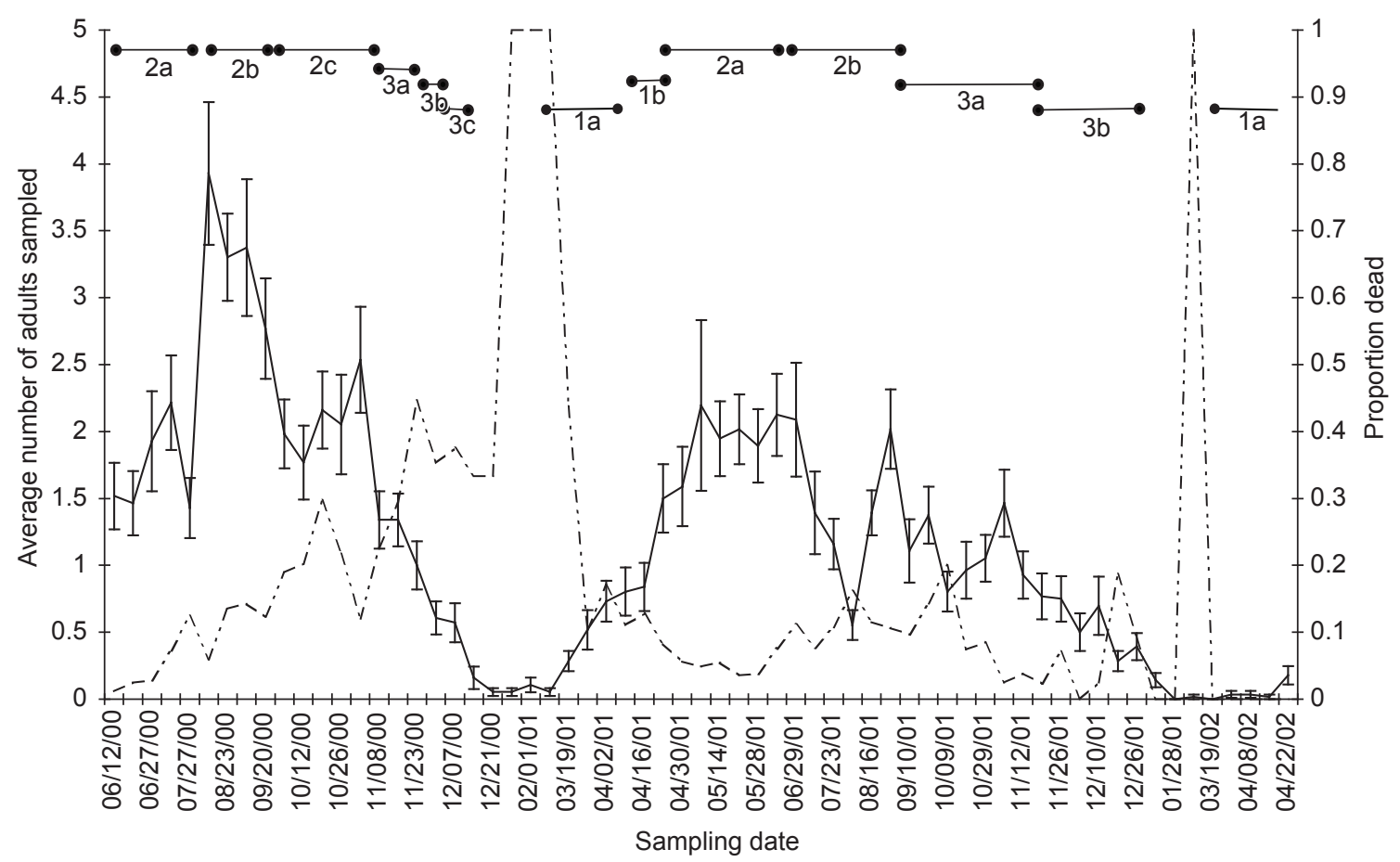

Fig. 1 - Temporal variation of the average number ( \pm EP) ( - ) and of the proportion of Oebalus poecilus adults dead (----) sampled in the bamboo litter. (1a: beginning of arrival; 1b: end of arrival; 2a: beginning of intermediate; 2b: intermediate; 2c: end of intermediate; 3a: beginning of departure; 3b: intermediate of departure; 3c: end of departure). Eldorado do Sul, RS, Brazil, 2000-2002. 
hibernation sites at the end of summer, and out of it in the spring, has been observed for other heteroptera such as N. viridula (Kiritani et al., 1962), O. pugnax (Nilakhe, 1976), B. l. leucopterus (Negron \& Riley, 1991), and E. heros (Panizzi \& Vivan, 1997).

When the present study began on June 2000, O. poecilus was already in the intermediate hibernation period. Based on the frequency distribution of the number of individual/sampling unit, on the total number on each sampling occasion, and on the insect's phenology, the periods described above were subdivided (Fig. 1).

The subdivisions in the arrival and departure periods indicate a gradual process of occupation and departure from the site by the bugs, which can be explained as an intrapopulational differential response to the diapause induction stimulus, which for $O$. poecilus occurs during the first three instars if individuals are exposed to photophases $\leq 13: 00 \mathrm{hL}$; in photophases $\geq 13: 50 \mathrm{hL}$ non-hibernating adultform emergence is induced (Albuquerque, 1989). Intermediate photoperiods induce emergence of both forms. Overlapping summer $O$. poecilus generations are estimated to be present in the field, giving rise to hibernating populations composed of individuals that perceive the stimulus at different moments.

The hibernation period of $O$. poecilus lasted between 7 and 8 months, close to that registered for O. pugnax in the Northern Hemisphere (Nilakhe, 1976). The duration of the hibernation period in Pentatomidae may be variable. Aner (1991) pointed out, for the same latitude as that of the present study, that Edessa meditabunda (De Geer) and T. limbativentris go through a 4 and 10 month hibernation period, respectively. Panizzi \& Vivan (1997) demonstrated that E. heros hibernation in Londrina, PR, Brazil, lasts 6 months. The differentiated hibernation period may also be related to a species' feeding behavior.

\section{Adult mortality}

Along the $1^{\text {st }}$ year of study, a trend towards proportional increase of dead individuals during the hibernation period was observed $(\mathrm{A}=67.0366$; $\left.\chi^{2}=68.0584 ; \mathrm{gl}=1 ; \mathrm{P}<0.001\right)$, which was not confirmed in the second year $(\mathrm{A}=-9.4247$; $\chi^{2}=1.0644 ; \mathrm{gl}=1 ; \mathrm{P}=0.3022$ ) (Fig. 1). The total proportion of dead individuals obtained for $O$. poecilus varied among the years, being significantly higher in $2000\left(\chi^{2}=51.8919 ; \mathrm{gl}=1 ; \mathrm{P}<0.001\right)$ (Table 1). For N. viridula Kiritani et al. (1962) registered mortalities of 38 and $86 \%$, depending on the hibernation site. For $O$. poecilus mortality was $15.8 \%$ in 2000 and $8.4 \%$ in 2001 (Table 1), allowing survivorship during hibernation in bamboo litter during the adverse periods.

The dead $O$. poecilus observed were grouped into three categories: intact (did not show any external alteration); parasitized (presented abdominal perforation); fungus-infected (showed fungus growth on external body surface) (Table 1).

The proportion of intact dead individuals was $c a .2 \%$ and did not differ between 2000 and $2001\left(\chi^{2}=0.1579 ; \mathrm{gl}=1 ; \mathrm{P}=0.6911\right)$ (Table 1). When comparing this proportion in periods and subperiods, a significant difference $(\mathrm{P}<0.01)$ was verified for subperiods $2 \mathrm{a}$ and $3 \mathrm{a}$ (2001), with the latter being higher. This suggests that at the end of hibernation natural mortality increases due to insufficient previously accumulated reserves to survive this period. Mielitz et al. (1996) also verified higher mortality when hibernation period of $O$. oryzae ended.

The proportion of parasitized individuals was ca. $1.3 \%$ and did not differ between years $\left(\chi^{2}=6.0703 ; \mathrm{gl}=1 ; \mathrm{P}=0.7910\right)($ Table 1$) ; 3.8 \%$ of the insects presented tachinid larvae in the abdominal cavity, with the greatest occurrence of these individuals when hibernation ended (Fig. 2).

TABLE 1

Total number of adults of Oebalus poecilus and dead individuals sampled in bamboo litter. Eldorado do Sul, RS, Brazil, 2000/02.

\begin{tabular}{|c|c|c|c|c|c|c|c|c|c|}
\hline \multirow[t]{3}{*}{ Year } & \multirow{3}{*}{$\begin{array}{l}\text { Number } \\
\text { of adults } \\
\text { sampled }\end{array}$} & \multicolumn{8}{|c|}{ Dead individuals } \\
\hline & & \multicolumn{2}{|c|}{ Intact } & \multicolumn{2}{|c|}{ Parasitized } & \multicolumn{2}{|c|}{ Infected by Fungus } & \multicolumn{2}{|c|}{ Total } \\
\hline & & $\mathrm{n}$ & $\%$ & n & $\%$ & $\mathbf{n}$ & $\%$ & $\mathbf{n}$ & $\%$ \\
\hline 2000 & 2101 & 40 & 1.9 & 29 & 1.4 & 263 & 12.5 & 332 & 15.8 \\
\hline 2001 & 2037 & 42 & 2.1 & 26 & 1.3 & 103 & 5.1 & 171 & 8.4 \\
\hline 2002 & 24 & 0 & 0 & 1 & 4.2 & 0 & 0 & 1 & 4.2 \\
\hline Total & 4162 & 82 & 2.0 & 56 & 1.3 & 366 & 8.8 & 504 & 12.1 \\
\hline
\end{tabular}




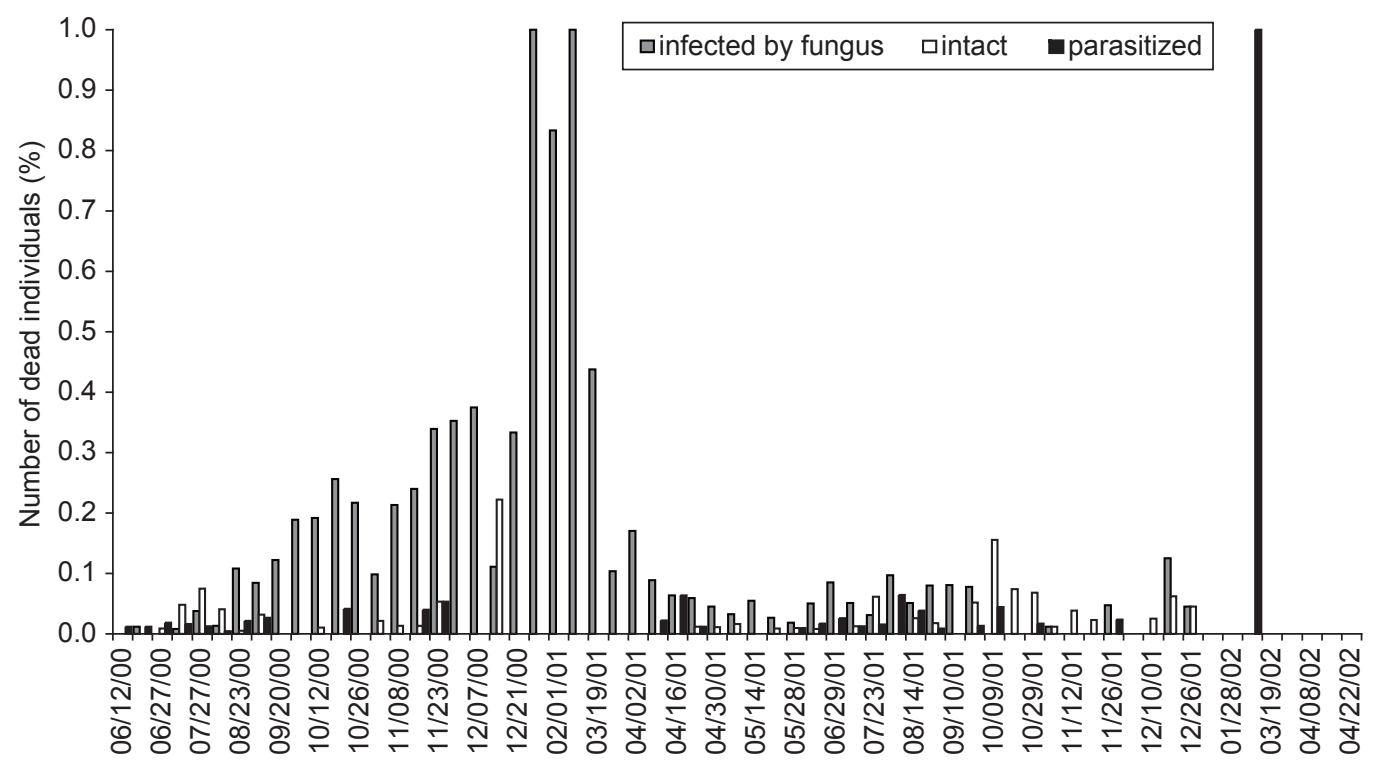

Sampling date

(a)

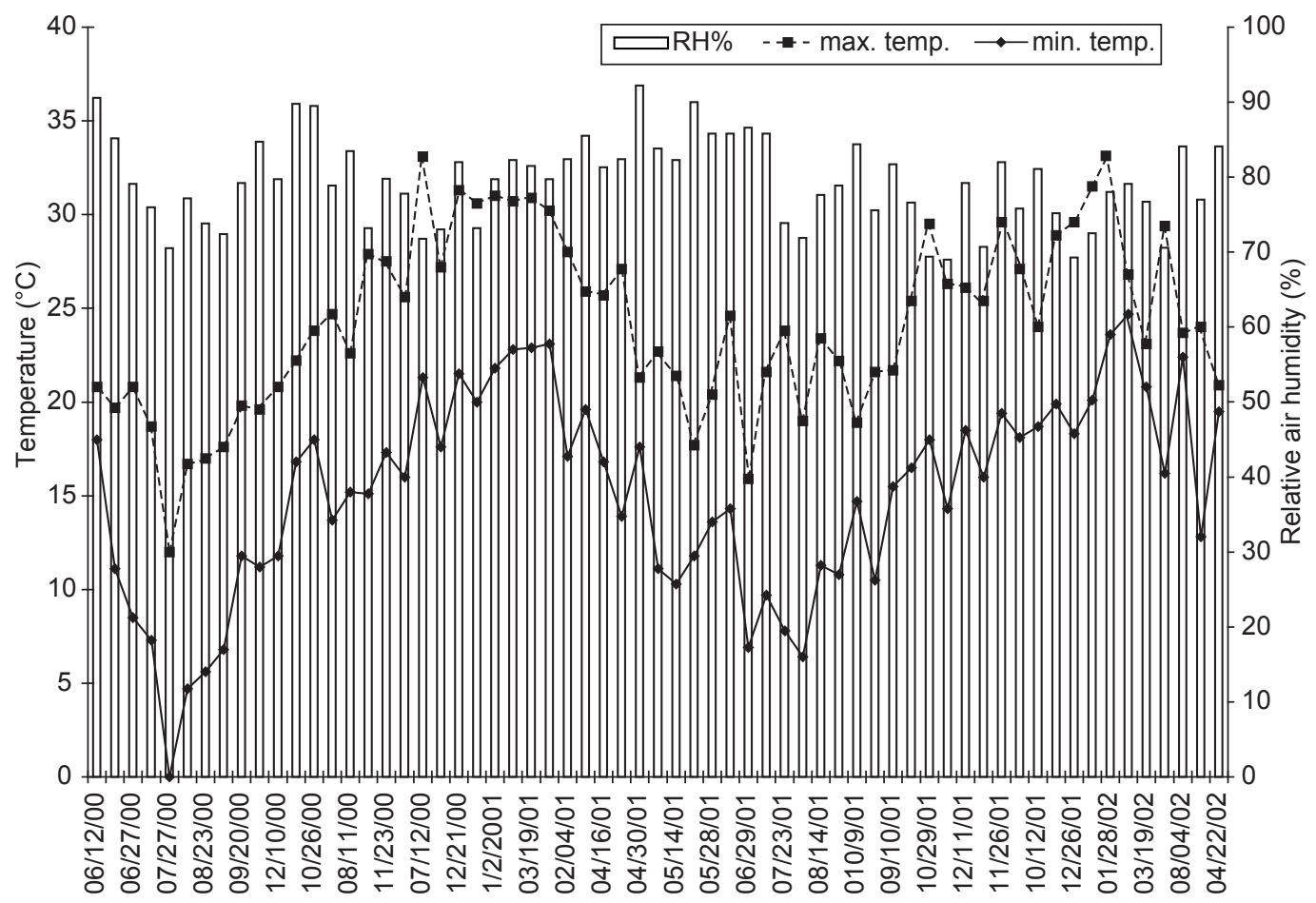

Sampling date

(b)

Fig. 2 - a) Temporal distribution of Oebalus poecilus dead individuals (proportion) sampled in the bamboo litter; and b) maximum (max. temp.) and minimum (min. temp.) air temperature and relative air humidity (RH\%) along the study. Eldorado do Sul, RS, Brazil, 2000-2002. 
The proportion of individuals infected by the fungus Beauveria bassiana (Bals.) Vuill. was $79.2 \%$ in 2000 and $60.2 \%$ in $2001\left(\chi^{2}=910.0765\right.$; $\mathrm{gl}=1 ; \mathrm{P}<0.001$ ) (Table 1). (The fungus was pathogenic to $O$. poecilus in the laboratory (Santos et al., 2002). Records of B. bassiana in hibernating populations of other insects are common (Tsuzuki et al., 1984; McGiffen \& Meyer, 1986; Lafleur et al., 1987; and Mielitz et al., 1996).) The proportion of individuals infected with $B$. bassiana increased with rising temperatures, mainly in 2000 (Fig. 2). This was also observed for Conotrachelus nenuphar (Herbst) (Coleoptera: Curculionidae) (McGiffen \& Meyer, 1986) and O. oryzae (Mielitz et al., 1996) during hibernation. The development of fungi as biological control agents in natural conditions is critically dependent on temperature and air humidity variations (Hallsworth \& Magan, 1999). The greater proportion of dead individuals infected with fungus in the $1^{\text {st }}$ year may have resulted from favorable temperature and relative air humidity conditions within the bamboo litter, and its high organic content coupled with the high bug-population density.

In spite of the majority of studies pointing to B. bassiana as an important mortality factor during hibernation, McCoy et al. (1988) report that this fungus is able to live on dead organic material (vegetation, and vertebrate and invertebrate organisms). Therefore, saprophytic action could be restricted to the end of a hibernation period.

Adults of $O$. poecilus remained in imaginal reproductive diapause from March to October at $30^{\circ} 02^{\prime} \mathrm{S}$ latitude. Since mortality was estimated as $c a .12 \%$, bamboo litter was demonstrated to be an important hibernation site for $O$. poecilus in the study area. In addition, increasing mortality factor effects on $O$. poecilus in hibernating sites may reduce infestation potential of this species in rice planted in Southern Brazil.

Acknowledgments - Gratitude is expressed to the National Council of Scientific and Technological Development (CNPqBrazil) for a fellowship to the first and second authors, and also to the Rio Grande do Sul State Foundation for Research Support (FAPERGS) for a fellowship given to the last author.

\section{REFERENCES}

ALBUQUERQUE, G. S., 1989, Ecologia de populações, biologia e estratégias da história de vida de Oebalus poecilus (Dallas, 1851) (Hemiptera: Pentatomidae). Dissertação (Ecologia), UFRGS, Porto Alegre, RS, 309p.

1991, Primeiro registro de ocorrência de Oebalus poecilus (Dallas, 1851) (Hemiptera: Pentatomidae) na cultura do sorgo (Sorghum bicolor (L.) Moench). An. Soc. Entomol. Brasil, 20: 219-220.

ANER, U., 1991, Pentatomídeos em hibernação em touceiras de gramíneas no município de Eldorado do Sul, RS (Insecta: Heteroptera: Pentatomidae). Dissertação (Ecologia), UFRGS, Porto Alegre, RS, 116p.

BECKER, M. \& GRAZIA-VIEIRA, J., 1971, Contribuição ao conhecimento da superfamília Pentatomoidea na Venezuela (Heteroptera). Iheringia, 40: 3-26.

GALLO,D., NAKANO, O., SILVEIRANETO, S., CARVALHO, R. P. L., BAPTISTA, G. C., BERTI FILHO, E., PARRA, J. R. P., ZUCCHI, R. A., ALVES, S. B., VENDRAMIM, J. D., MARCHINI, L. C., LOPES, J. R. S. \& OMOTO, C., 2002, Entomologia agrícola. FEALQ, Piracicaba, 920p.

GRAZIA-VIEIRA, J. \& CASINI, C. E., 1973, Lista preliminar dos heterópteros uruguaios da região nordeste: Pentatomidae e Coreidae (Insecta, Heteroptera). Iheringia, 44: 55-63.

HALLSWORTH, J. E. \& MAGAN, N., 1999, Water and temperature relations of growth of the entomogenous fungi Beauveria bassiana, Metarhizium anisopliae and Paecilomyces farinosus. J. Insect Pathol., 74: 261-266.

KIRITANI, K., 1963, The change in reproductive system of the southern green stink bug, Nezara viridula, and its application to forecasting of the seasonal history. Jap. J. Appl. Entomol. Zool., 7: 327-337.

KIRITANI, K., HOKYO, N. \& KIMURA, K., 1962, Differential winter mortality relative to sex in the population of the southern green stink bug, Nezara viridula, Pentatomidae, Hemiptera. Jap. J. Appl. Entomol. Zool., 6: 242-245.

LAFLEUR, G., HILL, S. B. \& VINCENT, C., 1987, Fall migration, hibernation site selection, and associated winter mortality of plum curculio (Coleoptera: Curculionidae) in a Quebec apple orchard. J. Econ. Entomol., 80: 1152-1172.

McCOY, C., SAMSON, R. A. \& BOUCIAS, D., 1988, Entomogenous fungi, pp. 151-236. In: C. M. Ignoffo (ed.), Handbook of natural pesticides. $5^{\circ}$ vol. CRC Press, Boca Raton.

McGIFFEN, JR. M. E. \& MEYER, J. R.,1986, Effect of environmental factors on overwintering phenomena and spring migration of the plum curculio, Conotrachelus nenuphar (Coleoptera: Curculionidae). Environ. Entomol., 15: $884-888$

MIELITZ, L. R., BECKER, M. \& ROMANOWSKI, H. P., 1996, Hibernation dynamics of Oryzophagus oryzae and its implications for management. Entomol. Exp. Appl., 78: $159-166$.

MOURÃO, A. P. M. \& PANIZZI, A. R., 2000, Diapausa e diferentes formas sazonais em Euschistus heros (Fabr.) (Hemiptera: Pentatomidae) no norte do Paraná. An. Soc. Entomol. Brasil, 29: 205-218.

NEGRON, J. F. \& RILEY, T. J., 1991, Seasonal migration and overwintering of the chinch bug (Hemiptera: Lygaeidae) in Louisiana. J. Econ. Entomol., 84: 1681-1685. 
NILAKHE, S. S., 1976, Overwintering, survival, fecundity, and mating behavior of the rice stink bug. Ann. Entomol. Soc. Am., 69: 717-720.

PANIZZI, A. R. \& NIVA, C. C., 1994, Overwintering strategy of the brown stink bug in northern Paraná. Pesq. Agropec. Bras., 29: 509-511.

PANIZZI, A. R. \& VIVAN, L. M., 1997, Seasonal abundance of the neotropical brown stink bug, Euschistus heros, in overwintering sites, and the breaking of dormancy. Entomol. Exp. Appl., 82: 213-217.

SANTOS, R. S. S., PRANDO, H. F., REDAELLI, L. R., DIEFENBACH, L. M. G. \& ROMANOWSKI, H. P., 2002, Ocorrência natural de Beauveria bassiana (Bals.) Vuill. Em adultos hibernantes de Oebalus poecilus (Dallas) (Hemiptera: Pentatomidae). Neotropical Entomology 31: 153-155.
SANTOS, R. S. S., REDAELLI, L. R., DIEFENBACH, L. M. G., ROMANOWSKI, H. P. \& PRANDO, H. F., 2003, Characterization of the imaginal reproductive diapause of Oebalus poecilus (Dallas) (Hemiptera: Pentatomidae). Braz. J. Biol., 63: 695-703.

SUTHERLAND, J. P., BAHARALLY, V. \& PERMAUL, D., 2002, Oebalus poecilus (Dallas, 1851) (Hemiptera: Pentatomidae) in Guyana. Entomotropica, 17: 97-101.

TSUZUKI, H., ASAYAMA, T., AMANO, T. et al., 1984, Studies on biology and control of the newly invaded insect rice water weevil (Lissorhoptrus oryzophilus Kuschel). Research Bulletin of the Aichi-Ken Agricultural Research Center Nagakute, 15: 1-148. 